Article

\title{
Natural Lighting for Sustainability of Cultural Heritage Refurbishment
}

\author{
Carla Balocco $^{1, * \mathbb{D}}$, Martina Cecchi ${ }^{2}$ and Giulia Volante ${ }^{1}$ \\ 1 Industrial Engineering Department, University of Florence, via Santa Marta 3, 50139 Firenze, Italy \\ 2 Freelance Civil Engineering Collaborating with the Industrial Engineering Department, \\ University of Florence, via Santa Marta 3, 50139 Firenze, Italy \\ * Correspondence: carla.balocco@unifi.it
}

Received: 11 August 2019; Accepted: 30 August 2019; Published: 5 September 2019

\begin{abstract}
Our present research, starting from a previous study, aimed to define a methodological approach for sustainable lighting designs in a historical library, focusing on lighting quality, mainly obtained from the optimal use of natural light and its combination with the artificial one. A historical Florentine monastery, which is now a university library, was used as a pilot project. The proposed method forms an essential part of widening and deepening the recent study. Results have shown that this method will allow for adaptive lighting, based on the optimal control and use of natural light, historical-philological re-reading of the space, cultural heritage preventive protection and conservation, with the aim of building adaptive reuse, and it can be extended to similar cultural heritage cases, but also non-listed buildings and current designs. This research demonstrates how a correct natural lighting design can be a tool for sustainable refurbishment, guaranteeing cultural heritage conservation and preventive protection, and recovery of the historical, architectural and philological value of old and/or listed buildings, which have been converted to uses, often diametrically opposed to the original ones.
\end{abstract}

Keywords: sustainable lighting; adaptive lighting; sustainability application; cultural heritage; library lighting; natural lighting control; LED lighting design

\section{Introduction}

Nowadays, energy control is of primary importance, for rational use of energy resources and a real economic and environmental sustainability of historic buildings management, as much as for the preservation and enhancement of their historical and architectural value. In the field of cultural heritage refurbishment and retrofitting, the lighting project has become really important as much as plant systems [1-6].

In particular, many comparative studies have shown the importance of the environmental impact of cultural heritage conservation and have revealed both single factors (e.g., natural and artificial light, temperature, relative humidity, indoor and outdoor microclimate and air pollution, etc.) and building architectural-structural features and materials (e.g., constructive technologies, air conditioning systems, heating plants, exhibits, etc.) and then, their correlated and cumulative effects [4-13]. It is always possible to modify the functional and distributive use of the indoor environment of any historical building, even when it has a strong cultural, social and religious value, with the aim of sustainability and adaptive re-use [14-17]. This fact proves that all the possibilities for conversion and adaptive re-use of historical buildings should define new functions with respect to the original ones and also quality and sustainability of different solutions from the following crucial points of view: formal, historical and cultural, constructive, material, distributive-functional and lighting [12,17]. In the last few years, the literature has focused on methodologies for the optimization of day-lighting use in public 
libraries, especially when housed in historical buildings, highlighting its positive effects (i.e., economic, management, social, cultural, political, energy and environmental [10,13-16]), for the connection between recovery and conservative restoration of valuable historical buildings, with adaptive reuse as an essential component of sustainable new design and/or refurbishment [11,12,17-22].

This issue is complex just because historical buildings have often been converted to different uses from the original ones and natural light quantity and distribution in the environment can become the cause of deterioration and damage for sensitive materials and objects [14,18-21].

With regard to the issue concerning damage caused by exposure to light (e.g., radiant heating, photochemical action, structural degradation), for the preventive conservation and protection of high light-sensitive materials, such as textiles, carpets, tapestries, costumes, prints, books and paper material, the maximum illuminance value suggested is $50 \mathrm{~lx}$. For low light-sensitive materials, such as stone materials, the suggested value is $300 \mathrm{~lx}$ and for average light-sensitive materials such as organic materials and wood, the suggested value is $150 \mathrm{~lx}$ [14,18-21].

Any retrofit and refurbishment solution for a new lighting system that does not recall the luminous climate belonging to the history of the building, does not allow the historical-philological reading of the space, does not transmit contents and information, can alter the visual perception up to making the space (historical building) even unrecognizable $[3,20,21]$. This issue is based on the wide and complex principle of the "Adaptive re-use of the built heritage" that, if achieved within a sustainable lighting project also for a "smart" renovation, can contribute to remarkable energy and economic results, social dynamism for city and territory, cultural heritage enhancement and protection and environmental sustainability. In this perspective, a great deal of recent literature is geared to the assessment of the adaptive re-use of buildings (i.e., historical buildings, protected and listed, recently built or newly designed) by means of applying Multicriteria Decision Analysis (MCDA), and Multi-Attribute Value Theory (MAVT) i.e., a particular kind of MCDA technique generally used [22-27].

Starting from the study and comparison of recent research $[3,28]$, the work presented here, provides an integrated approach for sustainable lighting design aimed at preventive conservation, energy saving and new technology application, with the maximum use, optimal control of natural light and efficient mix with the artificial light. The same building (i.e., a historical church converted into a university library) studied in [3], was used as a pilot and test project.

The aim of our research was to provide a methodological approach for assessing and applying the sustainability of lighting solutions developed as an adaptive re-lighting design of historical buildings, maximizing the use and control of natural light, with its optimal combination with artificial light, with a view to the well-known principle of the "Adaptive re-use of the built heritage: Preserving and enhancing the values of our built heritage for future generations" promoted by the EU. The adaptive re-use concept was connected to a natural lighting design based on its optimal mix with artificial light and effective control systems. In particular, the highly performing LED lighting technology was used for the new lighting proposal, due to its high efficiency, reduced dimensions and minimum weight, robustness, reliability, long life, absence of infrared and ultraviolet radiation, operation in very low safety voltage, no toxic or harmful substance. LED lighting does not require high power, allows for the obtainment of quality light, important energy savings, quality of vision and perception, guaranteeing protection and preventive conservation. These last aspects can be obtained by modulating the luminous intensity (dimming), adjusting the luminous flux and the correlated colour temperature as well as the emission spectrum, parameterization of the illumination, rationalization of the use of light (e.g., Passive Infrared sensor, PIR, application) setting and/or recall of different and integrated lighting scenarios, setting of dynamic light/colour sequences, scheduling of choreographic events, optimization of electricity use $[2,3,5,8]$. All these functions are stored inside the electronic ballast, others, such as sequences and schedules, are managed by control units or software, where it is possible to adjust and customize light management, precisely from the perspective of the reuse/re-illumination strategies for historic buildings based on decision-making processes [23-25]. 
The crucial issue of our research was to evaluate how a new natural lighting project based on the optimal control and mixing with artificial light, could foreground the historical, architectural, cultural and social value of historical buildings, as well as allow for the recovery of their high artistic and interpretive value with an important energy saving.

\section{Materials and Methods}

\subsection{References to Fundamentals Historical and Lighting Modelling in Existing Conditions}

Results of a previous study [3] within which an extensive study on historical, architectural and cultural aspects of the ancient church, its different indoor environments and the surrounding context, information from archives of rare printed books and literature sources, carried out together with lighting experimental measurements and simulations [3], formed the starting base.

Figure 1 shows the former minor seminary chapel, that is today a university library (i.e., currently Santa Marta library). The three dimensional model of the environment with the existing lighting system was used. The library belongs to the cultural heritage and is listed: this means that many building operations are not allowed on the windows (i.e., glazing and frame), architectural structures, roof and ceiling, walls and floor. The present library, housed in the apse of the historical church, is $10.93 \mathrm{~m}$ in length, $12.43 \mathrm{~m}$ in width and $9.82 \mathrm{~m}$ in height. The reading room is $22.93 \mathrm{~m}$ in length, $12.43 \mathrm{~m}$ in width and $10.62 \mathrm{~m}$ in height. Natural light only enters from vaulted openings placed in the highest part of the two side walls of the church. There are 29 single-glass windows placed at a height of $7.60 \mathrm{~m}$ from the floor: eight on the East and eight on the West walls, and 13 on the walls in the apse. Lighting simulation models, developed by using the commercial software Dialux-Evo-8.1, validated by experimental measurements and their results discussed in [3], were used for analyzing the library indoor space and, by means of particular attention for the improvement and great use and control of natural light, for assessing if the different illumination volumes identified in [3] could be re-designed for adaptive re-use of the former chapel.
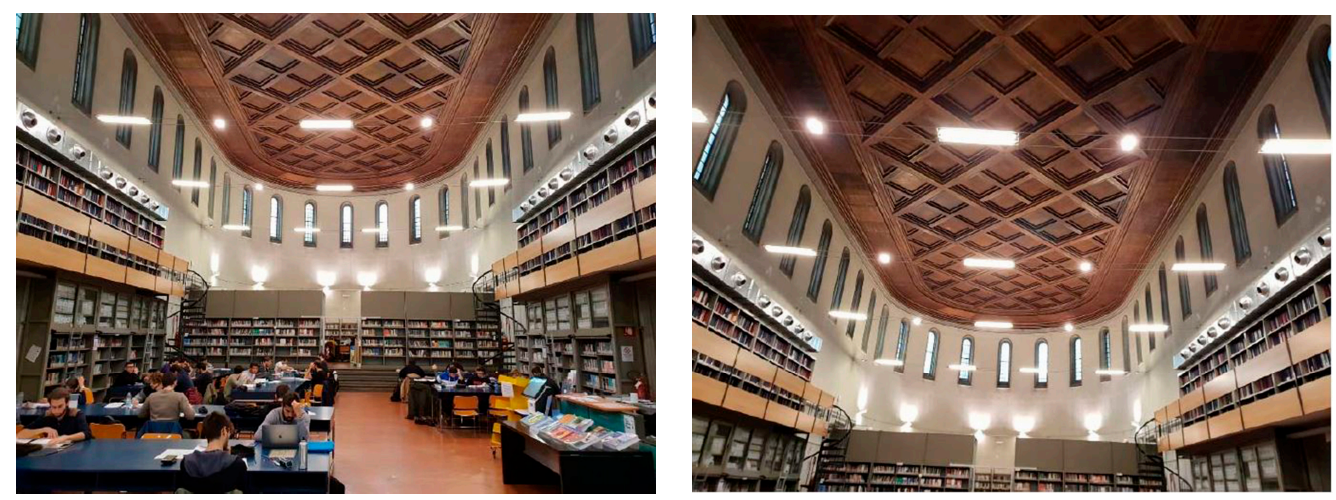

Figure 1. Photo: two views of the University Library housed in the Seminary Chapel.

\subsection{Maximizing Natural Light Use and Control: A New Lighting Proposal}

For identifying new lighting scenarios based on natural lighting optimal control and use, the three zones defined in [3] were exploited: illuminance values and photosensitivity classes of present materials (i.e., reading room, apse room with paper material, manuscripts, books with important historical value, and media room) were taken into account. The new light concept was based on the enhancement of the adaptive re-use of the historical chapel and then on a lighting design performed for the highest use of natural light and its effective control, oriented to the different integrated specializations and services that constitute the library system, that is today Santa Marta University library.

The new lighting proposal was characterized by reversibility, easy maintenance and possibility of disassembly and removal of all the elements/components. In particular, higher performances, quality 
and efficiency of the chosen LED systems for the project proposal can be deduced by comparing the existing (Table 1) with those used (Table 2) referring to basic and crucial metrics [28-35].

Table 1. Existing lighting system—technical and photometric data.

\begin{tabular}{|c|c|c|c|c|c|c|}
\hline $\begin{array}{l}\text { Commercial } \\
\text { Name }\end{array}$ & Lamp Type & $\begin{array}{c}\text { Photometric } \\
\text { Curve }\end{array}$ & $\begin{array}{c}\text { Ratio between } \\
\text { Luminous Flux and } \\
\text { Power }(1 \mathrm{~m} / \mathrm{W})\end{array}$ & $\begin{array}{c}\text { Correlated } \\
\text { Colour } \\
\text { Temperature (K) }\end{array}$ & $\begin{array}{l}\text { N. Installed } \\
\text { Luminaries }\end{array}$ & $\begin{array}{l}\text { Height from } \\
\text { Floor }(\mathrm{m})\end{array}$ \\
\hline 3F LINDA & LED & & $5200 / 58$ & 3000 & 6 & 3.00 \\
\hline Steel LED & LED & & $2145 / 58$ & 5000 & 8 & 6.51 \\
\hline Afrodita & LED & & $6600 / 70$ & 3000 & 6 & 3.34 \\
\hline Canes & $\begin{array}{l}\text { Compact } \\
\text { fluorescent } \\
\text { lamp }\end{array}$ & & $1500 / 36$ & 4000 & 6 & 4.50 \\
\hline $\begin{array}{l}\text { Damp Proof } \\
\text { LED }\end{array}$ & LED & & $1000 / 39$ & 4000 & 4 & 2.20 \\
\hline F30 LED & LED & & $2000 / 150$ & 4000 & 2 & 6.00 \\
\hline Tubular & $\begin{array}{l}\text { Compact } \\
\text { fluorescent } \\
\text { lamp }\end{array}$ & & $5000 / 49$ & 2000 & 32 & 6.51 \\
\hline
\end{tabular}

All the new LEDs were assembled on transversal electrified tracks that would reuse the same electrical supply system of the existing tracks (Figure 2). Solar radiation and daylight control (i.e., for lighting and thermal effects) were obtained by the evaluation of the transient condition of the hourly variation of the incidence angle of solar radiation on the splayed arched windows referring to the modeling method suggested in [36]. Therefore, hourly values of the transparency coefficient were calculated. Table 3 shows as an example the hourly values for two typical days, 21 December and 21 June. 

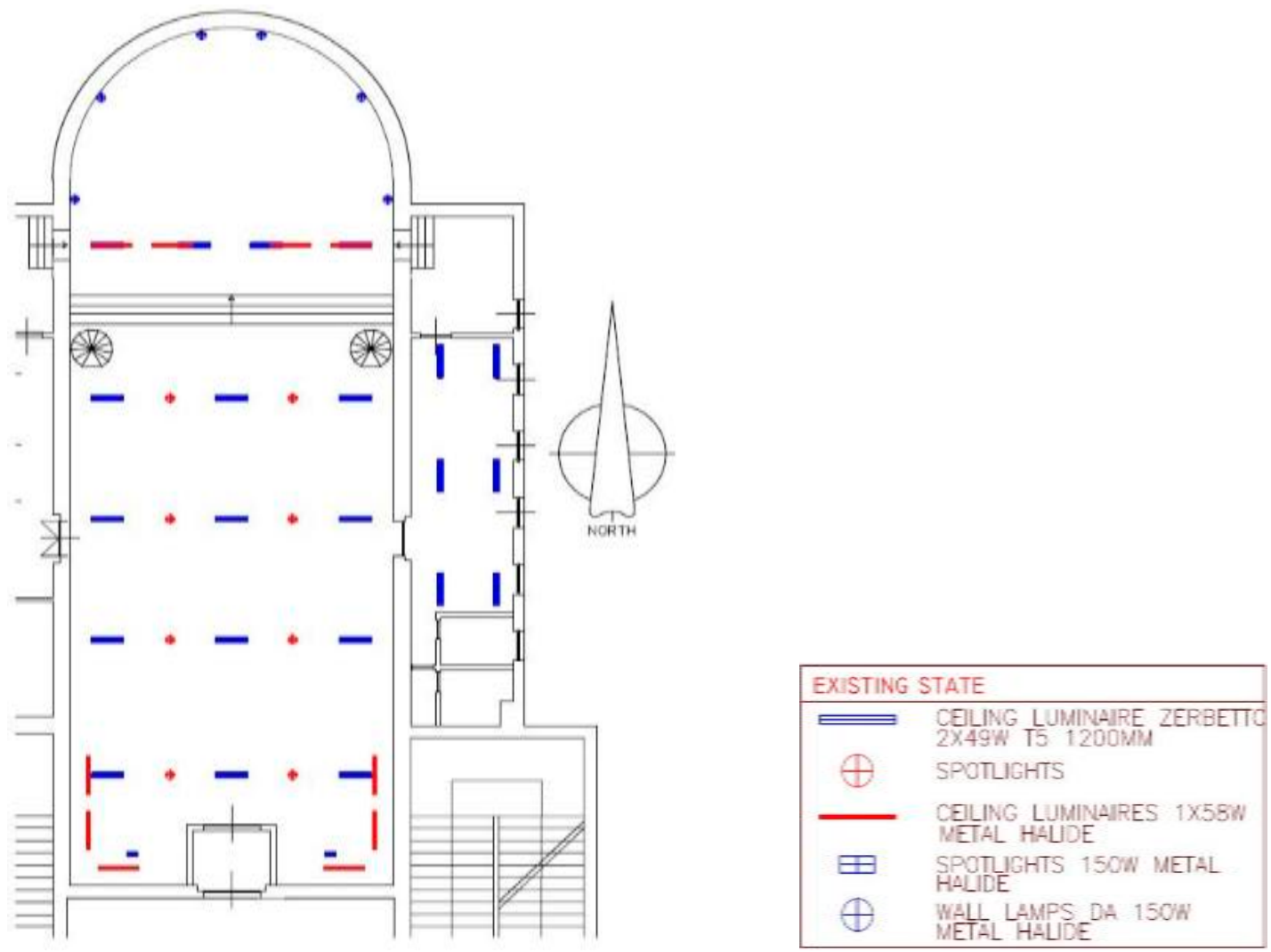

(a)

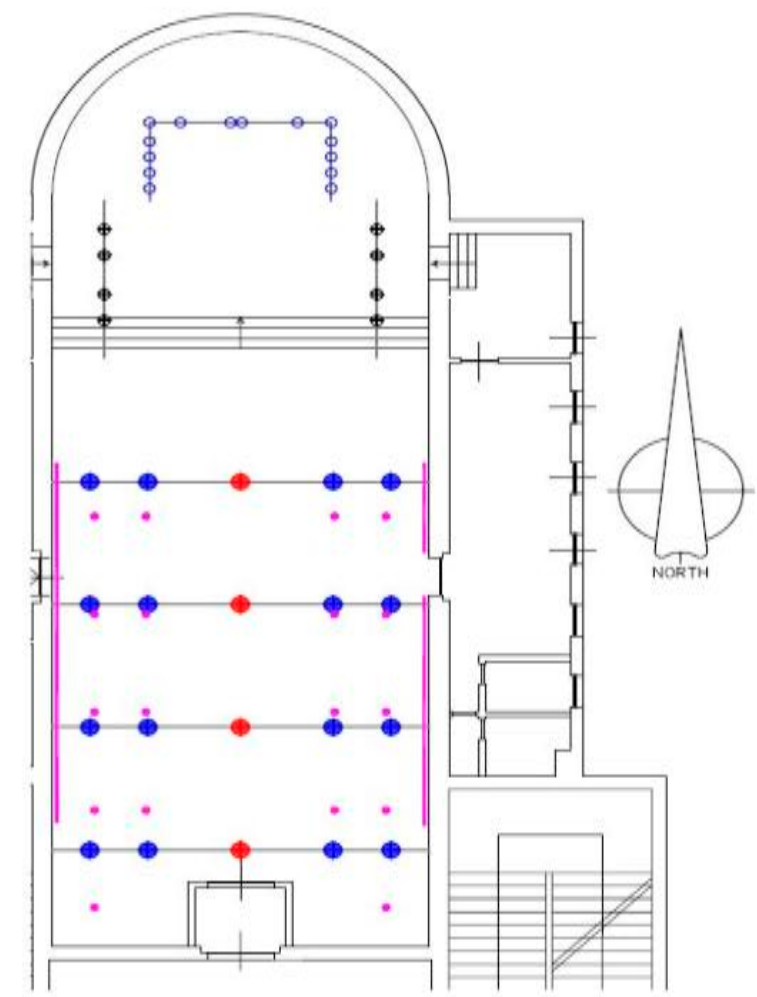

\begin{tabular}{|cl|}
\hline NEW LIGHTING SYSTEM \\
\hline \multirow{2}{*}{} & LUCY \\
PARSCAN \\
OPTEC \\
$\oplus$ PARSCAN ZOOM \\
- & OPTEC WALLWASHER \\
\hline & STRIP LED FURNITURE \\
\hline
\end{tabular}

(b)

Figure 2. Map of luminaries and electrified tracks: existing state (a) and new lighting proposal (b). 
Table 2. Technical data of the new lighting system-project solution.

\begin{tabular}{|c|c|c|c|c|c|c|c|c|c|c|}
\hline $\begin{array}{l}\text { Commercial } \\
\text { Name }\end{array}$ & Lamp Type & $\begin{array}{l}\text { Control } \\
\text { System }\end{array}$ & $\begin{array}{c}\text { Photometric } \\
\text { Curve }\end{array}$ & $\begin{array}{c}\text { Ratio between } \\
\text { Luminous Flux and } \\
\text { Power }(\mathrm{lm} / \mathrm{W})\end{array}$ & $\mathbf{R a}$ & $\mathbf{R f}$ & Rg & $\begin{array}{l}\text { Correlated Colour } \\
\text { Temperature (K) }\end{array}$ & $\begin{array}{l}\text { N. Installed } \\
\text { Luminaries }\end{array}$ & $\begin{array}{l}\text { Height from } \\
\text { Floor (m) }\end{array}$ \\
\hline \multicolumn{11}{|l|}{ Optec } \\
\hline Wallwasher & LED & DALI & & $511 / 8.6$ & 92 & 90 & 100 & 3000 & 8 & 5.51 \\
\hline \multicolumn{11}{|l|}{ Optec } \\
\hline Washer & LED & DALI & & $4685 / 36$ & 92 & 90 & 99 & 4000 & 4 & 6.51 \\
\hline Parscan Zoom & LED & DALI & & $630 / 6$ & 92 & 90 & 100 & 3000 & 14 & 5.51 \\
\hline Parscan Zoom & LED & DALI & & $1161 / 14$ & 92 & 90 & 99 & 4000 & 16 & 6.51 \\
\hline Lucy & LED & Dimmer & & $221 / 13$ & 92 & 90 & 100 & 3000 & 18 & 1.50 \\
\hline
\end{tabular}


Table 3. Hourly values of the transparency coefficient, as a function of the incidence angle of solar radiation.

\begin{tabular}{lllll}
\hline Hour & $\begin{array}{l}\text { Transparency East } \\
\text { 21 December }\end{array}$ & $\begin{array}{l}\text { Transparency East } \\
\text { 21 June }\end{array}$ & $\begin{array}{l}\text { Transparency West } \\
\text { 21 December }\end{array}$ & $\begin{array}{l}\text { Transparency West } \\
\text { 21 June }\end{array}$ \\
\hline 5 & 0 & 0.636 & 0 & 0 \\
6 & 0 & 0.765 & 0 & 0.587 \\
7 & 0 & 0.810 & 0 & 0.767 \\
8 & 0.872 & 0.823 & 0.161 & 0.831 \\
9 & 0.874 & 0.820 & 0.472 & 0.854 \\
10 & 0.875 & 0.797 & 0.640 & 0.869 \\
11 & 0.862 & 0.725 & 0.714 & 0.875 \\
12 & 0.839 & 0.532 & 0.734 & 0.876 \\
13 & 0.779 & 0.134 & 0.714 & 0.875 \\
14 & 0.577 & 0 & 0.640 & 0.869 \\
15 & 0.150 & 0 & 0.472 & 0.854 \\
16 & 0 & 0 & 0.161 & 0.831 \\
17 & 0 & 0 & 0 & 0.767 \\
18 & 0 & 0 & 0 & 0.587 \\
19 & 0 & 0 & 0 & 0.245 \\
\hline
\end{tabular}

Transparence index results were used for lighting transient simulations of the existing state and new lighting proposal, performed with Dialux-Evo-8.1, taking into account the different luminous conditions of the external environment due to the specific latitude (i.e., for Florence $43^{\circ} 47^{\prime} 14^{\prime \prime} 64 \mathrm{~N}$ Latitude), hourly sun position, hourly solar radiation, hourly values of illuminance and corresponding sky conditions, specifically calculated for the case study as a function of different orientations and inclinations of walls and windows, starting from data and information provided by the Centre LAMMA CNR IBIMET of Florence (in particular, located in Sesto Fiorentino, near Florence, via Madonna del Piano, Italy).

A solution of integration of matte surfaces, that exploit the splaying of the windows with a diffusing double sails system, was studied for the new lighting project. The existing transversal electrified tracks were also used for the suspension and fixing of two sail systems made of polyester fabric with braided and thermo-fixed PVC-coated thread, which had light diffusion (i.e., opaline surface) and sound-absorbing properties. The installation of these two sail systems together with the covering of all the splayed arched windows with a matte surface, provided an optimal control of natural and artificial lighting. Quantity of natural light distribution and diffusion in the environment, were evaluated by means of different transient simulations.

The different lighting scenarios identified in [3] (i.e., museum-philological-historical connected to the whole church; functional library connected to the reading/writing zone of the nave and aisles; exhibition connected to apse zone) were simulated using the aforementioned natural light control systems and the new LED sources, designing and checking the specific beam and aiming angles, position, and the connected efficient control system with which these LEDs were equipped (Table 2). In particular, the choices concerning selection and positioning of LED sources, (referring to their correlated colour temperature, emission spectrum, light angle beam, photometric curve luminous flux, efficiency [28-35,37,38]), were as follows: LED strips on all the shelving for books in the reading zone and working with presence sensors; dimmable LED lights on the display case working and dimmable to not exceed $50 \mathrm{~lx}$ as suggested for the exposure of high photosensitive objects [39]; presence sensors for the whole church in relation to the museum lighting scenario; workstations with an "on board" element in order to reduce energy consumption, guarantee high removability and reversibility, as well as optimal specific lighting for visual tasks; spotlights on the electrified tracks for the reading zone with a tilt angle of $30^{\circ}$; wall-washers LED lights for narrow beam grazing lighting along the two perimetral walls in the zone between the apse and the two sail systems; spotlight LEDs with a tilt angle of $+30^{\circ}$ and $-30^{\circ}$ depending on display case type and position for the museum zone. 
Moreover, all the LED lights arranged in a horseshoe shape for the apse zone, would recall the chandeliers of the historical churches and then their form, which was due to an adaptive and sustainable choice in terms of energy and monetary costs. Emergency lights were connected to the electrified tracks and positioned in the nave both at the entrance zone and the centre of the church.

Because of low daylight levels, dimming systems were used for LED sources grouping luminaires in different control zones depending on their natural light availability in connection with a specific part of the environment corresponding to the aforementioned zones: this choice can provide important energy savings as well as those demonstrated in the literature $[8,10,40-43]$. For the exhibition scenario, a Passive Infrared system (PIR) was used for light dimming and control.

The quantity and quality of incoming natural light and the obtained effects of diffusion obtained by means of matte surfaces combined with the two sail systems were assessed by simulation result post-processing.

\section{Results and Discussion}

Results of the proposed lighting solution showed the new design efficacy in the context of adaptive re-use and sustainable lighting: it ensured preventive conservation, efficient energy use and optimal daylighting combined with sustainable control and efficient LED technology solutions.

The dimensionless Modelling index (M) suggested in [44] that describes the balance between diffuse and directed light, being the ratio of semi-cylindrical illuminance (Esc) to vertical illuminance (Ev) at a studied point, was evaluated for each new lighting scenario, in the precautionary condition of mix between the highest levels of natural and artificial light (i.e., artificial lighting system operating at $100 \%$ without dimming and control and in the morning at 10 a.m.) and referring to a $1.2 \mathrm{~m}$ height from the floor for people sitting and $1.6 \mathrm{~m}$ height for people standing, as required for the average cylindrical illuminance maintained (Esc) evaluation. The $\mathrm{M}$ index value for the apse zone and for the whole library/reading zone, was within the limits [28,44], which was the range 0.8-1.3. Due to the important dimensions of the environment in terms of height, floor area and total volume, the $\mathrm{M}$ index use was possible, also for the indoor lighting condition, by means of a congruent adaptation of the calculation method.

Table 4 provides the obtained results for the different lighting scenarios that prove light optimal mix, good distribution and uniformity, and goodness of light modelling. The $\mathrm{M}$ index results, achieved for all the new lighting scenarios, demonstrate that adaptive re-use integrated with adaptive re-lighting of existing and historical buildings, based on the optimal control and mixing between natural and artificial light, foreground the historical, architectural, cultural and social value of buildings, as well as allowed for the recovery of their social, cultural, high artistic and interpretive value, with visual and ergonomics comfort, quality of vision and perception and important energy saving.

Table 4. Basic illumination and Modelling Index values—new lighting proposal.

\begin{tabular}{|c|c|c|c|c|c|}
\hline & Parameters & $\begin{array}{c}100 \% \\
\text { Working }\end{array}$ & Museum-Philological_Historical & $\begin{array}{c}\text { Functional } \\
\text { Library }\end{array}$ & Exhibition \\
\hline \multirow{4}{*}{ Apse } & $\operatorname{Esc}(1.2 \mathrm{~m}) \mathrm{lx}$ & 17.5 & 42.6 & 8.03 & 51.6 \\
\hline & $\operatorname{Esc}(1.6 \mathrm{~m}) \mathrm{lx}$ & 17.2 & 45.7 & 8.25 & 58.3 \\
\hline & Ev $(1.2 \mathrm{~m}) \mathrm{lx}$ & 14.4 & 46.8 & 5.19 & 62.4 \\
\hline & Ev $(1.6 \mathrm{~m}) \mathrm{lx}$ & 13.5 & 48.7 & 6.09 & 67.3 \\
\hline \multirow{4}{*}{ Reading Room } & Esc $(1.2 \mathrm{~m}) \mathrm{lx}$ & 58.1 & 22.2 & 54.2 & 17.5 \\
\hline & $\operatorname{Esc}(1.6 \mathrm{~m}) \mathrm{lx}$ & 54.2 & 22.1 & 51.9 & 18.0 \\
\hline & Ev $(1.2 \mathrm{~m}) \mathrm{lx}$ & 45.0 & 20.1 & 44.8 & 14.2 \\
\hline & Ev $(1.6 \mathrm{~m}) \mathrm{lx}$ & 42.7 & 21.4 & 42.5 & 14.1 \\
\hline \multirow{4}{*}{$\begin{array}{c}\text { Modelling } \\
\text { Index } \\
(\mathrm{M}=\mathrm{Esc} / \mathrm{Ev})\end{array}$} & Apse (1.2 m) & 1.21 & 0.91 & 1.55 & 0.83 \\
\hline & Apse (1.6 m) & 1.27 & 0.94 & 1.35 & 0.87 \\
\hline & Reading room $(1.2 \mathrm{~m})$ & 1.29 & 1.11 & 1.20 & 1.23 \\
\hline & Reading room $(1.6 \mathrm{~m})$ & 1.27 & 1.04 & 1.22 & 1.27 \\
\hline
\end{tabular}


Figure 3 shows the comparison between results obtained for the functional-library scenario for the existing conditions and with the artificial lighting system operating at $100 \%$ and in the morning at 10 a.m. with maximum natural light illuminance levels. Moreover, the lighting solution for the apse zone (exhibition scenario), guaranteed light quality and uniform distribution and especially the illuminance values for preventive conservation and protection (Figure 4). The optimal combination could be noted between natural and artificial light (Figures 4 and 5, bottom left and right two views of exhibition scenario rendering).

In the apse zone, a typical, commercial showcase for the book heritage was used and illuminated when visitors approached. The $50 \mathrm{~lx}$ limit value was guaranteed [31,32,34,39] by means of light control for the optimal mix between natural and artificial, and a dedicated dimming system for the apse. This also guaranteed respect for energy exposure (i.e., annual light dose) that represented the maximum recommended annual value, expressed in klx per hour/year (LO) which, as suggested [39], must not have exceeded $150 \mathrm{klx}$. In precautionary conditions (i.e. maximum use of the library, all artificial light working at full power, combined with the presence of maximum natural light) the obtained LO was $125 \mathrm{klx}$ hour/year. This LO value was obtained taking into account the whole year with LED lighting regulated and dimmed for all the visual tasks expected from the different lighting scenarios, and, in particular, for the maximum of $50 \mathrm{~lx}$ on the display case in the apse zone.
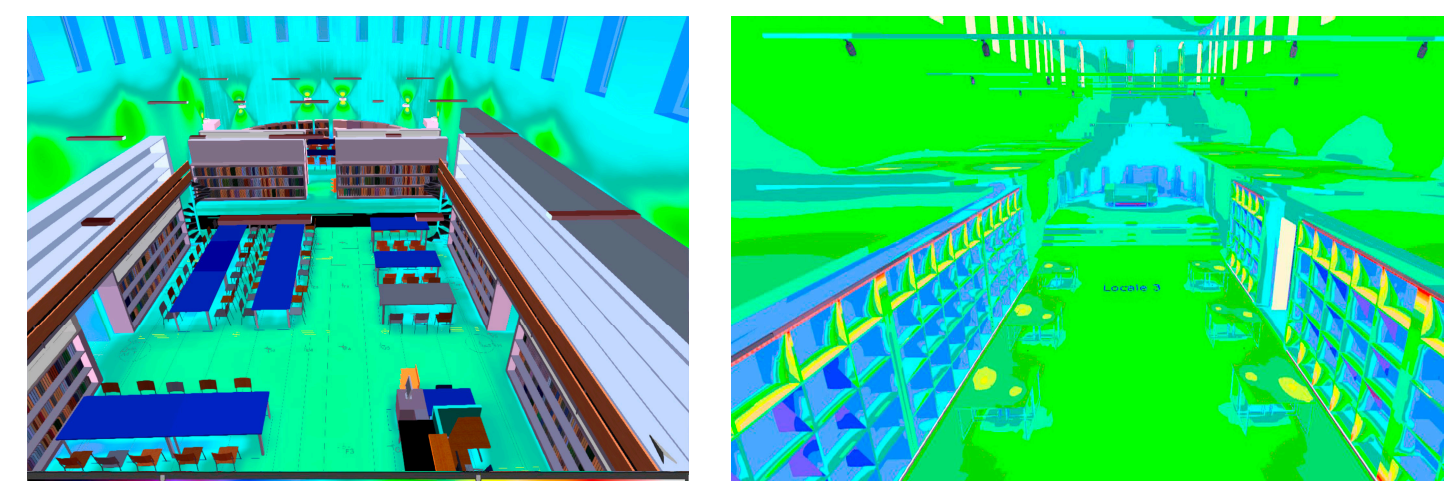

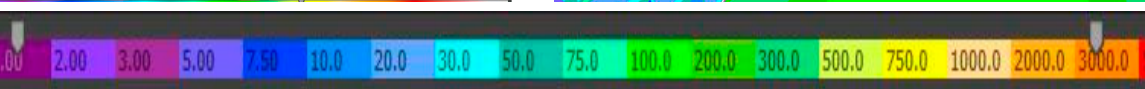

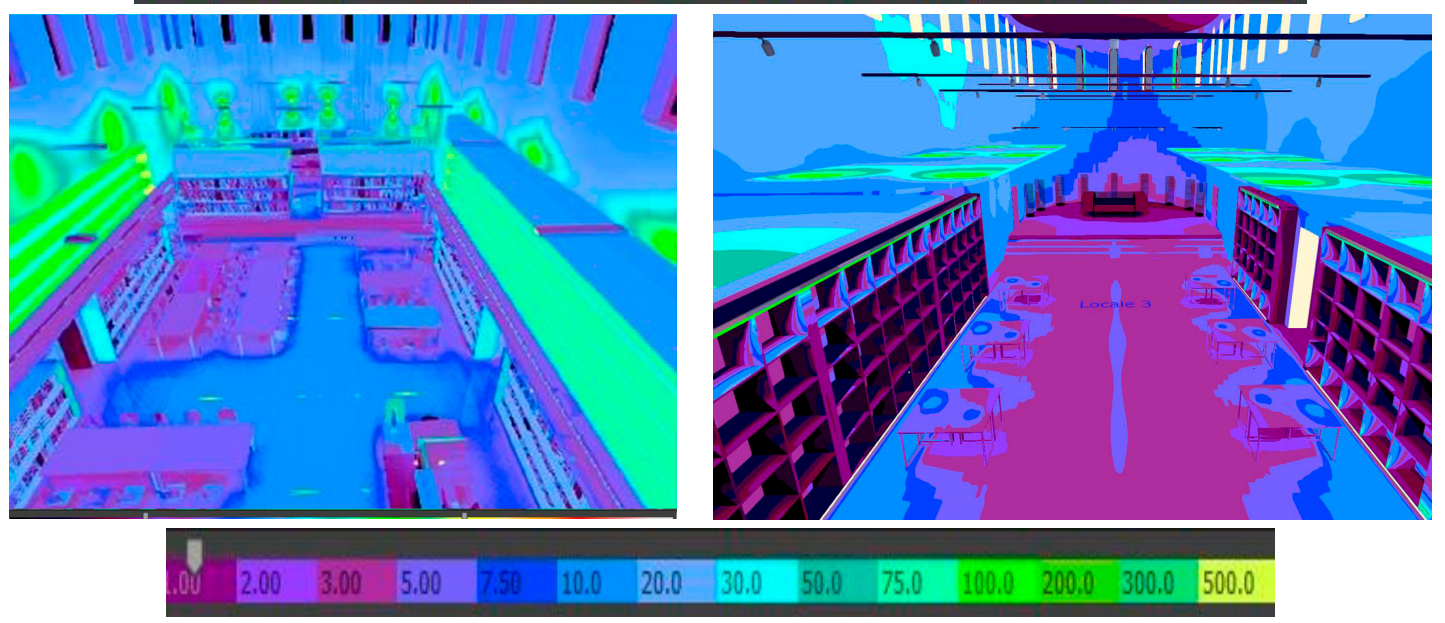

Figure 3. The illuminance (lx) and luminance $\left(\mathrm{cd} / \mathrm{m}^{2}\right)$ distribution at 10 a.m. for the functional-library scenario: (top left) illuminance at the existing state; (top right) illuminance distribution of the new lighting solution; (bottom left) luminance distribution at the existing state; (bottom right) luminance distribution of the new lighting solution. 
Figure 5 provides all the rendering results of new lighting design (functional-library scenario) obtained for cautionary conditions: $10 \mathrm{a} . \mathrm{m}$. and 2 p.m. with mixing between natural and artificial light and all the LED luminaries working $100 \%$.

For all the scenarios, the proposed lighting solutions guaranteed visual comfort and ergonomics and the absence of glare phenomena. In particular, the lighting solution for the functional library scenario, assessed at 2 p.m. as a cautionary choice, because of the maximum natural light incoming combined with full working conditions of the artificial light sources, provides uniform distribution of illuminance and luminance equilibrium (Figure 5).

The limit values due to standards for all the work planes and visual tasks and, in particular, on the vertical plane of all the open shelved books, under the two sail systems, where the mean illuminance level is always in the range 75-158 lx during morning use of the library, are guaranteed (Table 5). As a matter of fact, the current standards [30,31,33,34,39,45] suggest the following minimum threshold values for Illuminance average value (Em), illuminance uniformity (U0, the ratio between minimum illumination and average illumination on the studied surface) and colour rendering index (Ra), to guarantee visual comfort and vision ergonomics: meeting rooms and common areas for students $200 \mathrm{~lx}(\mathrm{Em}), 0.4$ (U0) and 80 (Ra); libraries and reading areas $500 \mathrm{~lx}(\mathrm{Em}), 0.6$ (U0) and 80 (Ra); libraries shelves books 200 lx (Em), 0.6 (U0) and 80 (Ra); repository archives 330 lx (Em), 0.4 (U0) and $80(\mathrm{Ra})$; writing/reading, writing at PC station, data processing $500 \mathrm{~lx}(\mathrm{Em}), 0.6(\mathrm{U} 0)$ and 80 (Ra); reception desk- benches $300 \mathrm{~lx}(\mathrm{Em}), 0.6$ (U0) and 80 (Ra); library deposits $200 \mathrm{~lx}$ (Em), 0.4 (U0) and $80(\mathrm{Ra})$. In particular, Table 5 provides the results of the minimum, maximum and mean illuminance values, for the Reading plane, Desk-reception plane and Apse-plane, calculated on the working level at $0.75 \mathrm{~m}$, in precautionary conditions (worst condition due to the co-presence of natural and artificial light) with all the luminaries working at 100\% and maximum external solar radiation, i.e., the highest sunshine (light intensity) value.
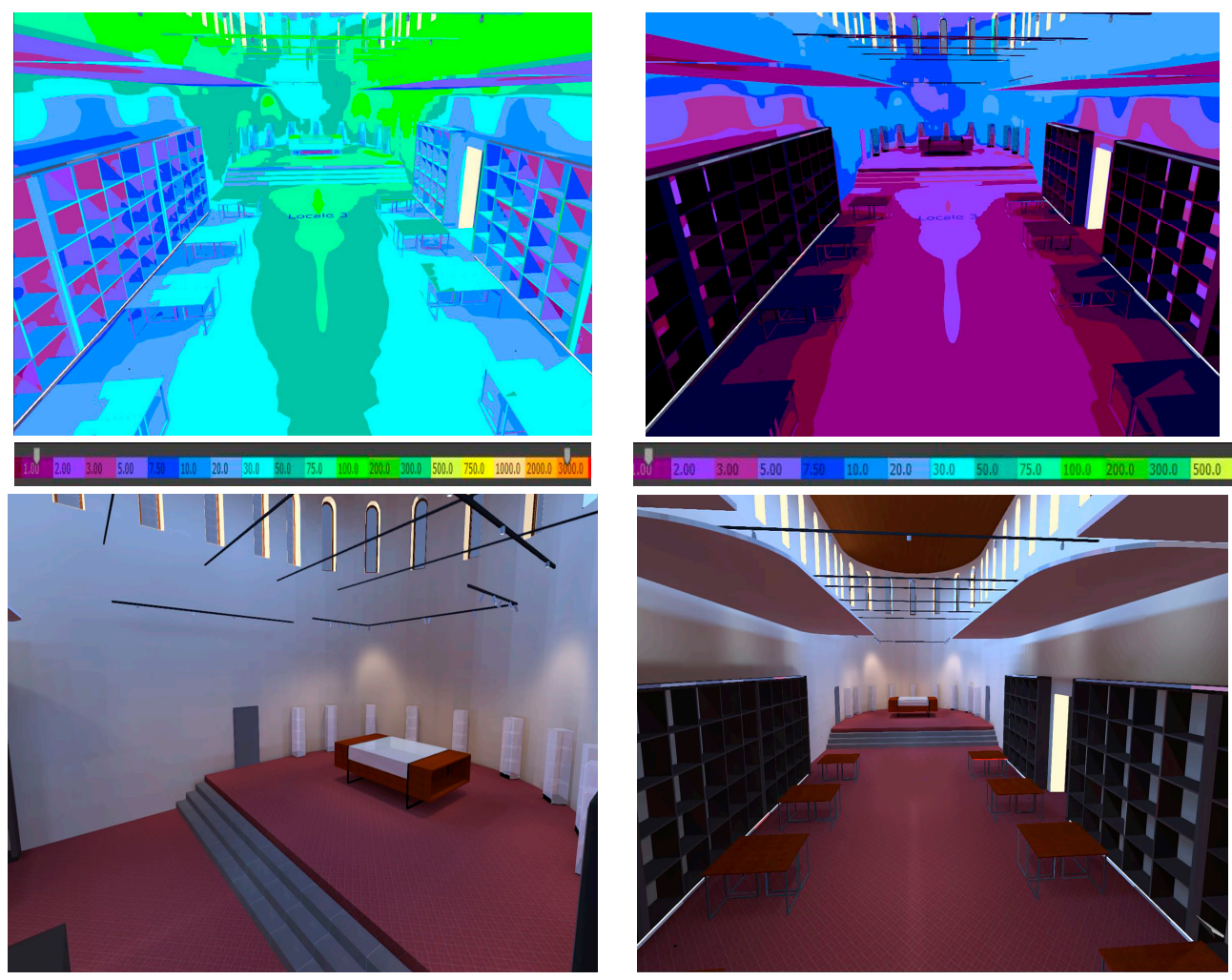

Figure 4. Exhibition scenario in the afternoon at 2 p.m.: illuminance values (left top; $1 x$ ) and luminance values (right top; $\mathrm{cd} / \mathrm{m}^{2}$ ) Rendering: view from the apse (bottom left) and view from the entrance (bottom right). 
Table 5. Illuminance values (lx)—new lighting proposal.

\begin{tabular}{cccc}
\hline & Reading Plane (1x) & Desk-Reception Plane (1x) & Apse Plane (1x) \\
\hline$E_{\text {min }}$ & 129 & 45 & 10 \\
\hline$E_{\max }$ & 670 & 398 & 114 \\
\hline$E_{\text {mean }}$ & 329 & 154 & 50.3 \\
\hline
\end{tabular}

The luminance values were evaluated on the side walls and floor of the reading room, on the floor of the apse zone and on a virtual calculation plane taken at the ceiling level, immediately below the two sail systems, in the precautionary lighting condition due to the artificial lighting system operating at $100 \%$ and in the morning at 10 a.m. with maximum natural light illuminance values (Table 6). The uniformity of distribution of the luminance values can be seen as well as their compliance with those suggested for correct vision and quality of perception (Table 6).
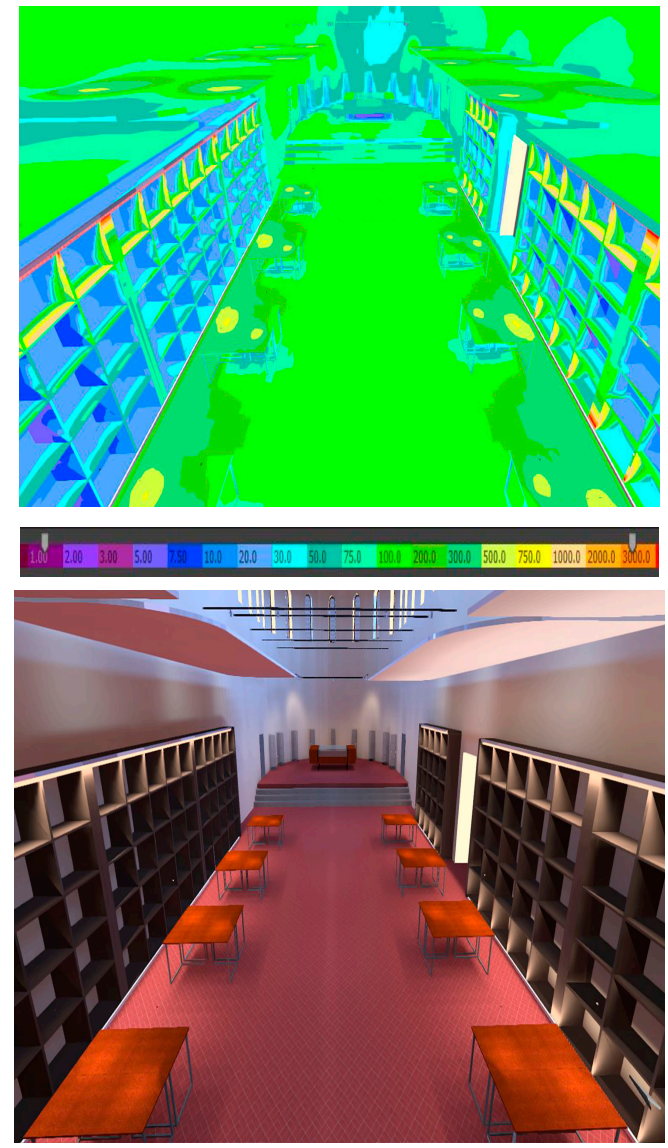
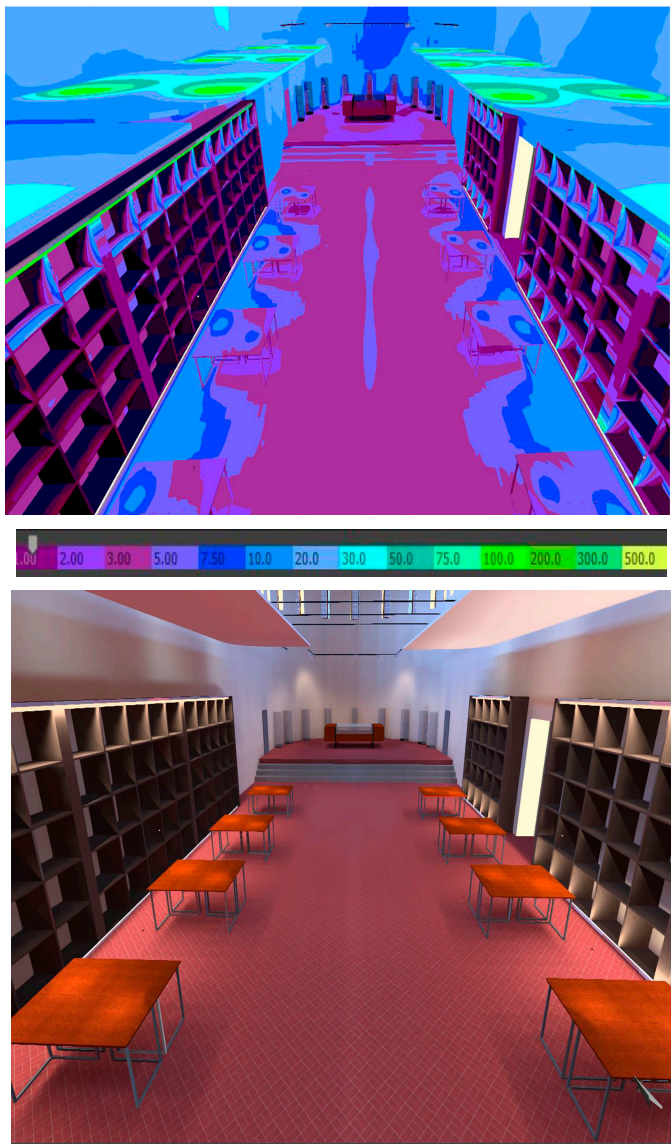

Figure 5. New lighting design (functional-library scenario) obtained for cautionary conditions with mixing between natural and artificial light and all the LED luminaries 100\% working at 10 a.m.: (top left) false colours render of illuminance values (lx); (top right) false colours render of illuminance values $\left(\mathrm{cd} / \mathrm{m}^{2}\right)$; (bottom left) rendering at 10 a.m. and (bottom right) rendering at 2 p.m. 
Table 6. Luminance values $\left(\mathrm{cd} / \mathrm{m}^{2}\right)$-new lighting proposal.

\begin{tabular}{|c|c|c|c|c|c|c|c|}
\hline & $\left(\mathrm{cd} / \mathrm{m}^{2}\right)$ & $\begin{array}{l}\text { East } \\
\text { Wall }\end{array}$ & $\begin{array}{l}\text { West } \\
\text { Wall }\end{array}$ & $\begin{array}{l}\text { Apse } \\
\text { Wall }\end{array}$ & $\begin{array}{c}\text { Reading } \\
\text { Room Floor }\end{array}$ & $\begin{array}{l}\text { Apse } \\
\text { Floor }\end{array}$ & $\begin{array}{l}\text { Whole } \\
\text { Ceiling }\end{array}$ \\
\hline \multirow{3}{*}{$\begin{array}{c}\text { Functional } \\
\text { Library }\end{array}$} & $\mathrm{L}_{\min }$ & 0.40 & 0.28 & 0.80 & 0.035 & 0.04 & 0.50 \\
\hline & $\mathrm{L}_{\max }$ & 37.7 & 10.5 & 1.66 & 12.7 & 2.99 & 2.28 \\
\hline & $\mathrm{L}_{\text {mean }}$ & 4.64 & 3.62 & 1.42 & 3.85 & 0.7 & 1.15 \\
\hline \multirow{3}{*}{ Exhibition } & $\mathrm{L}_{\min }$ & 0.06 & 0.07 & 0.15 & 0.01 & 0.03 & 0.38 \\
\hline & $\mathrm{L}_{\max }$ & 6.52 & 9.06 & 6.63 & 2.47 & 1.98 & 2.09 \\
\hline & $\mathrm{L}_{\text {mean }}$ & 1.71 & 1.64 & 1.81 & 0.71 & 1.03 & 0.90 \\
\hline \multirow{3}{*}{$\begin{array}{c}\text { Museum } \\
\text { Philological- } \\
\text { History }\end{array}$} & $\mathrm{L}_{\min }$ & 0.1 & 0.11 & 0.25 & 0.02 & 0.04 & 0.46 \\
\hline & $\mathrm{L}_{\max }$ & 10.9 & 9.47 & 6.82 & 4.11 & 2.81 & 2.13 \\
\hline & $\mathrm{L}_{\text {mean }}$ & 2.75 & 2.61 & 2.06 & 1.17 & 1.26 & 1.02 \\
\hline \multirow{3}{*}{$100 \%$ working } & $\mathrm{L}_{\min }$ & 0.41 & 0.34 & 0.85 & 0.037 & 0.06 & 0.52 \\
\hline & $\mathrm{L}_{\max }$ & 37.8 & 10.5 & 6.80 & 12.8 & 3.04 & 2.27 \\
\hline & $\mathrm{L}_{\text {mean }}$ & 4.77 & 3.81 & 2.94 & 3.85 & 1.36 & 1.17 \\
\hline \multirow{3}{*}{$\begin{array}{l}\text { Existing } \\
\text { state }\end{array}$} & $\mathrm{L}_{\min }$ & 0 & 0.001 & 1.65 & 0.005 & 0.12 & 0.001 \\
\hline & $\mathrm{L}_{\max }$ & 727 & 72.5 & 36.43 & 14.6 & 16.3 & 11.2 \\
\hline & $\mathrm{L}_{\text {mean }}$ & 12 & 17.2 & 14.30 & 6.02 & 4.44 & 3.06 \\
\hline
\end{tabular}

The uniform distribution of illuminance and luminance levels due only to natural light was assessed: the solution of integration of matte surfaces with the two sail systems guarantees the absence of any glare phenomena and quality of vision and perception when solar radiation get to the highest illuminance values (Table 6, Figure 6).
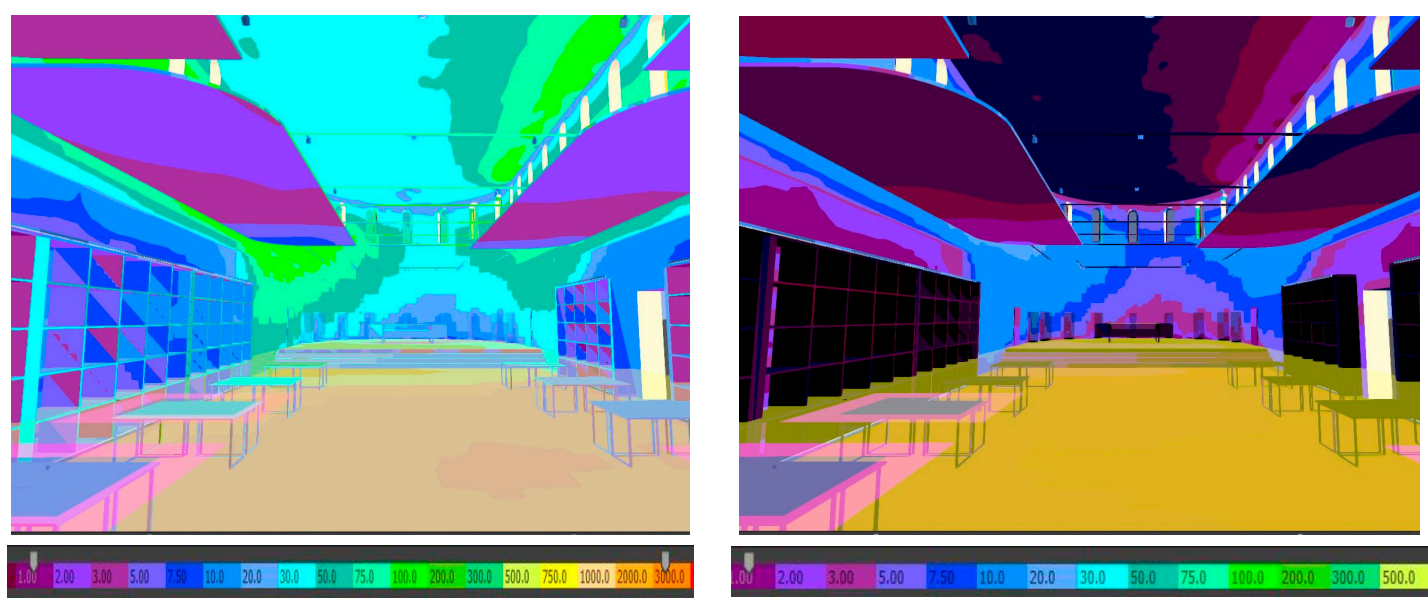

Figure 6. Illuminance values (left; $1 \mathrm{x}$ ) and luminance values (right; $\mathrm{cd} / \mathrm{m}^{2}$ ) at 10 a.m.-only natural light (artificial light off) for the functional library scenario design; a view below the sails system.

The contrast rendering factor $(\mathrm{C} \%)$ was evaluated referring to the optimal contrast value for vision and perception expected for the specific visual task, and evaluated as the ratio between the luminance for two work planes of two desks (L2) taken as tests and the luminance of the background (L1), the floor been taken as a reference because it was the most important, significant surface. These work planes corresponded to the worst lighting conditions in the existing state: the first desk (Desk 01, desk_left) was on the left side of the library and was in darkness with very low illumination values, and the second (Desk 02, desk_right) was on the right side under the higher illuminance values, due to natural light.

Results are provided in Table 7: the optimal mix of natural and artificial light obtained by the new lighting proposal ensured the homogeneity of the luminance ratios that respected the limit values [30,32], and the contrast factor values, for both the considered work planes, in compliance with 
the suggested values [30,32]. This fact always guaranteed optimal viewing conditions for the specific visual task.

Table 7. Contrast assessment—new lighting proposal.

\begin{tabular}{lccc}
\hline & $\mathbf{L}_{\mathbf{2}}\left(\mathbf{c d} / \mathbf{m}^{2}\right)$ & $\mathbf{L}_{\mathbf{1}}\left(\mathbf{c d} / \mathbf{m}^{\mathbf{2}}\right)$ & $\mathbf{C}(\mathbf{\%})$ \\
\hline Desk 01 (morning/functional library) & 4.64 & 4.41 & 5.21 \\
\hline Desk 02 (morning/functional library) & 5.27 & 4.41 & 19.5 \\
\hline Desk 01 (evening/functional library) & 4.29 & 3.85 & 11.4 \\
\hline Desk 02 (evening/functional library) & 4.58 & 3.85 & 19 \\
\hline
\end{tabular}

In particular, considering the illuminance and luminance levels only due to the artificial lighting system working at $100 \%$, in the evening (at 6 p.m. without natural light) the quality and sustainability of the new lighting design was guaranteed by the efficient and effective control/regulation system and high performing LED lighting: Figure 7 shows results obtained for the functional-library scenario.
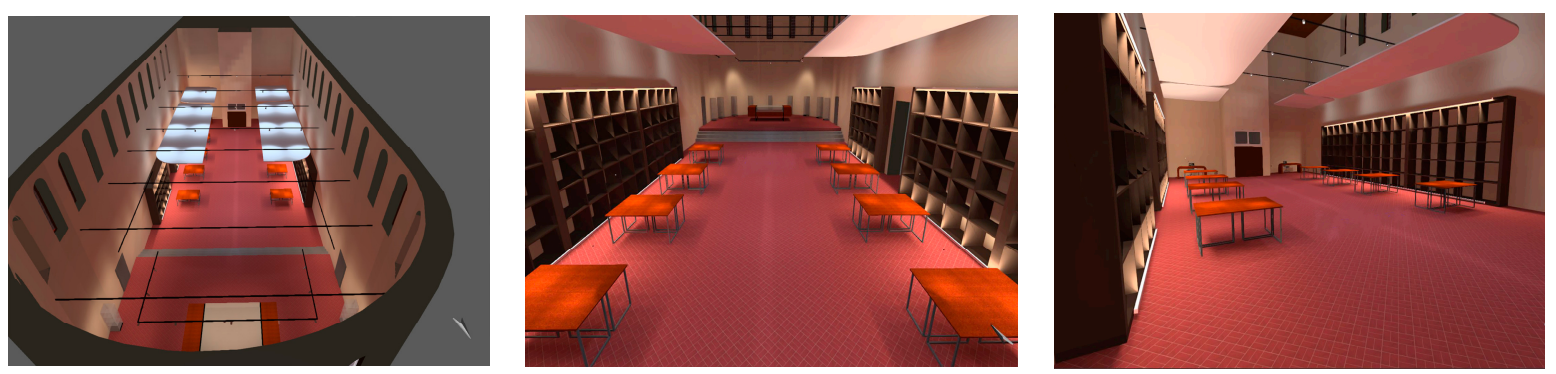

Figure 7. Different rendering views: from left to right rendering of new lighting design (functionallibrary scenario) obtained with all the LED luminaries at 100\% working conditions in the evening at 6 p.m. (without natural light).

In Figure 8 the new lighting for the museum-philological-historical scenario, obtained for cautionary conditions with mixing between natural and artificial light and all the LED luminaries 100\% working, in the morning at 10 a.m., is shown with different views.
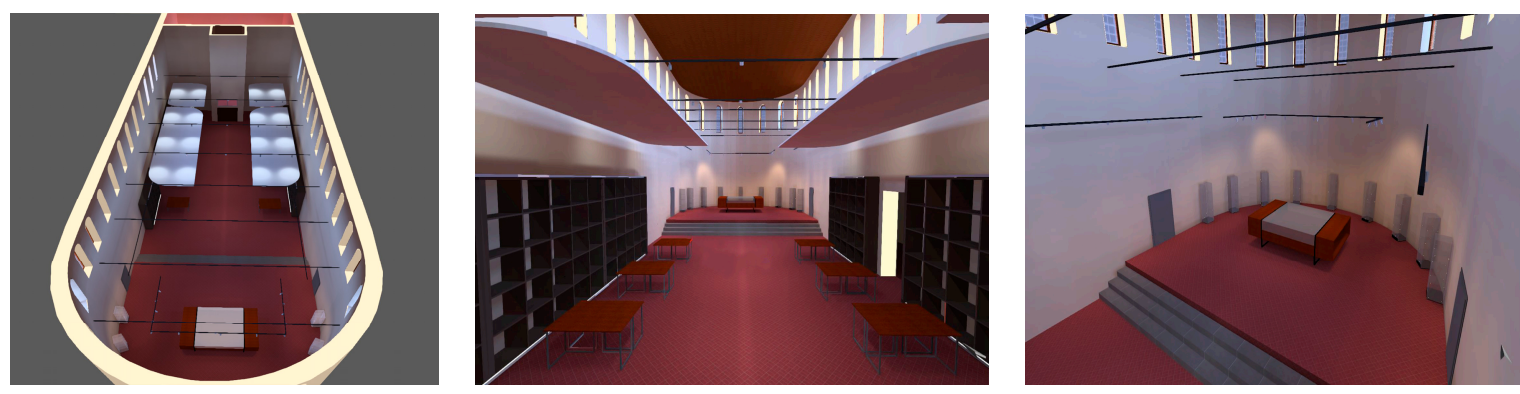

Figure 8. Different rendering views: from left to right rendering of new lighting design (museumphilological-historical scenario) obtained for cautionary conditions with mixing between natural and artificial light and all the LED luminaries 100\% working, in the morning at 10 a.m.

Energy performance and efficiency of the lighting proposal (and for all the lighting scenarios) was evaluated by means of the Lighting Energy Numeric Indicator (LENI), total energy consumption and costs [32]. Taking into account the operating conditions of the regulation system, as reported in Table 8 , designed for each control group dedicated to the corresponding LED group, the average percentage incidence of the control/regulation system on the energy consumption (i.e., the LENI indicator) for all the lighting scenarios achieved 3\%, due to the high efficiency of the LED lighting system used. 
Table 8. Identified operating conditions of the control/regulation system of the LED luminaries for all the different scenarios of the adaptive re-lighting proposal.

\begin{tabular}{cccccc}
\hline Proposed Lighting Scenarios & $\begin{array}{c}\text { LED Reading } \\
\text { Room }\end{array}$ & $\begin{array}{c}\text { LED Media } \\
\text { Room }\end{array}$ & $\begin{array}{c}\text { LED Reading } \\
\text { Room }\end{array}$ & $\begin{array}{c}\text { LED Apse } \\
\text { Zone }\end{array}$ & LED Cases \\
\hline Functional-library & $100 \%$ operating & $100 \%$ operating & $100 \%$ operating & off & Off \\
\hline Museum-philological-historical & off & Off & $100 \%$ operating & $100 \%$ operating & Off \\
\hline Exhibition & off & Off & $60 \%$ operating & off & $\begin{array}{c}\text { switch on } \\
\text { passing }\end{array}$ \\
\hline
\end{tabular}

Table 9 shows results in comparison with the existing state: the appreciable, strong reduction of LENI, annual energy consumption and costs can be noted.

Table 9. Lighting Energy Numeric Indicator, Energy consumption and costs—new lighting proposal.

\begin{tabular}{ccccc}
\hline & $\begin{array}{c}\text { Existing } \\
\text { State }\end{array}$ & Museum-Philological-History & $\begin{array}{c}\text { Functional } \\
\text { Library }\end{array}$ & Exhibition \\
\hline $\begin{array}{c}\text { Consumption } \\
\mathbf{( k W h / y e a r )}\end{array}$ & $10,300-15,100$ & $4650-7000$ & $4200-6300$ & $4200-6300$ \\
\hline Costs (€/year) & $3093-4528$ & $1400-2100$ & $1260-1890$ & $1260-1890$ \\
\hline LENI (kWh/year/m $\left.\mathbf{m}^{\mathbf{2}}\right)$ & $22-23$ & $11-17$ & $10-15$ & $10-15$ \\
\hline
\end{tabular}

\section{Conclusions}

The aim of our research was to provide a methodological approach for applying sustainability to lighting solutions developed as an adaptive re-lighting design of historical buildings, with optimal use and control of natural light. Therefore, the adaptive re-use concept was connected to a natural lighting design based on its optimal mix with artificial light and effective control systems.

All the current changes in economic, social, natural, environmental, urban and energy factors, really affect choices and projects for existing and historical buildings re-use. The proposed method allows adaptive re-lighting design solutions that ensure the recovery of historical, philological and cultural value of the existing/historical buildings together with revaluation, transformation (cultural, functional), reorganization and redistribution of their environments, especially if converted to different uses such as a (university, public) library.

The method is also a tool for adaptive re-use and re-lighting designs aimed at environmental and energy sustainability by means of comprehensive-integrated preservation and management (energy and economics) systems, optimization of natural lighting use, protection, improvement and increase of the cultural, historical and social awareness, especially for integration and entanglement of libraries with creative and smart cities $[20,23,25,27]$.

The proposed sustainable lighting and adaptive reuse application, shows how it is possible to design quality lighting, by reversible solutions, easily removable, maximizing the use of natural light with a correct and effective control for its mingling with the artificial one, obtaining not only visual comfort, reduction of energy consumption and costs (including those related to maintenance) but also compliance with the limit values envisaged for different visual tasks, vision ergonomics and quality of perception.

By extension, the proposed method leads to the identification of efficient, effective sustainable lighting solutions (natural light design integrated with LED lighting systems and their effective control) in compliance with cultural heritage adaptive reuse and preventive conservation concepts.

The proposed method can also be a useful tool for adaptive re-lighting design and sustainability oriented towards a Human and User Centric Lighting design, a principle that expresses and guarantees the positive effects of light and lighting on people's health, well-being and activity, but also health, 
protection and preventive conservation of works and objects of cultural heritage, with both short and long term benefits, energy consumption reduction and environmental sustainability.

Author Contributions: Conceptualization, C.B.; data curation, M.C. and G.V.; formal analysis, C.B., M.C. and G.V.; investigation, C.B.; methodology, C.B.; software, M.C. and G.V.; supervision, C.B.; validation, G.V.; visualization, M.C.; writing-review and editing, C.B.

Funding: This research is part of a wider ranging strategic project of the University of Florence, "Preliminary technical and economic feasibility projects on University of Florence strategic interventions, inside an experimental laboratory, year 2018-2019", by which the one-year research grant was financed.

Acknowledgments: All the authors thank Francesco Napolitano (Architect), Head of the Executive Office, Head of Security and Protection Department and Construction Area Manager of the University of Florence, and the Staff of the Technical Construction Area of the University of Florence, for cooperation and support in this research; Simonetta Pagnini, General Director, Paolo Baldi Director of Santa Marta Library and his staff, for cooperation during experimental monitoring; Silvia Cremasco, Lighting Design Department, ERCO Lighting, Milan; Marco Rosselli Industrial Engineering technician for suggestions during lighting modeling; Luca Fibbi of the Centre "LAMMA CNR IBIMET" of Florence, for providing all the climate data needed for this study.

Conflicts of Interest: The authors declare no conflicts of interest. The funders had no role in the design of the study; in the collection, analyses, or interpretation of data; in the writing of the manuscript, or in the decision to publish the results.

\section{References}

1. Camuffo, D.; Pagan, E.; Bernardi, A.; Becherini, F. The impact of heating, lighting and people in re-using historical buildings: A case study. J. Cult. Herit. 2004, 5, 409-416. [CrossRef]

2. Lucchi, E. Review of preventive conservation in museum buildings. J. Cult. Herit. 2018, 29, 180-193. [CrossRef]

3. Balocco, C.; Volante, G. A Method for Sustainable Lighting, Preventive Conservation, Energy Design and Technology_Lighting a Historical Church Converted into a University Library. Sustainability 2019, 11, 3145. [CrossRef]

4. Luther, M.B.; Horan, P.; Tokede, O.O. A case study in performance measurements for the retrofitting of a library. Energy Build. 2018, 169, 473-483. [CrossRef]

5. Salvadori, G.; Fantozzi, F.; Rocca, M.; Leccese, F. The Energy Audit Activity Focused on the Lighting Systems in Historical Buildings. Energies 2016, 9, 998. [CrossRef]

6. Cirrincione, L.; Nucara, A.; Peri, G.; Rizzo, G.; Scaccianoce, G. Two operative risk indicators as tools for negotiating contracts between curators of Museums and HVAC technical services providers. J. Cult. Herit. 2019. [CrossRef]

7. Leccese, F.; Salvadori, G.; Morozzi, R.; Nieri, P. Feltrin Study on the suitable lighting design of Beato Angelico's artworks displayed at the National Museum of San Matteo in Pisa (Italy). IOP Conf. Ser. Mater. Sci. Eng. 2018, 364, 012095. [CrossRef]

8. Dubois, M.-C.; Bisegna, F.; Gentile, N.; Knoop, M.; Matusiak, B.; Osterhaus, W.; Tetri, E. Retrofitting the Electric Lighting and Daylighting Systems to Reduce Energy Use in Buildings: A Literature Review. Energy Res. J. 2015, 6, 25-41. [CrossRef]

9. Esther, H.K.; Chan Yung, E.H.W. Implementation challenges to the adaptive reuse of heritage buildings: Towards 1, the goals of sustainable, low carbon cities. Habitat Int. 2012, 36, 352-361.

10. Burattini, C.; Nardecchia, F.; Bisegna, F.; Cellucci, L.; Gugliermetti, F.; Vollaro, A.D.L.; Salata, F.; Golasi, I. Methodological Approach to the Energy Analysis of Unconstrained Historical Buildings. Sustainability 2015, 7, 10428-10444. [CrossRef]

11. Petković-Grozdanovića, N.; Stoiljković, B.; Keković, A.; Murgul, V. The Possibilities for Conversion and Adaptive Reuse of Industrial Facilities into Residential Dwellings. Procedia Eng. 2016, 165, 1836-1844. [CrossRef]

12. Rani, P. The Impact of Adaptive Reusing Heritage Building as Assessed by the Indoor Air Quality Case study:UNESCO World Heritage Site Penang. Procedia Soc. Behav. Sci. 2015, 179, 297-307. [CrossRef]

13. Salata, F.; Golasi, I.; Di Salvatore, M.; Vollaro, A.D.L. Energy and reliability optimization of a system that combines daylighting and artificial sources. A case study carried out in academic buildings. Appl. Energy 2016, 169, 250-266. [CrossRef] 
14. Zeren Mine, T. Adaptive re-use of monuments "restoring religious buildings with different uses". J. Cult. Herit. 2013, 145, 514-519.

15. Omar, O.; García-Fernández, B.; Fernández-Balbuena, A.Á.; Vázquez-Moliní, D. Optimization of daylight utilization in energy saving application on the library in faculty of architecture, design and built environment, Beirut Arab University. Alex. Eng. J. 2018, 57, 3921-3930. [CrossRef]

16. Doulos, L.; Kontadakis, A.; Madias, E.; Sinou, M.; Tsangrassoulis, A. Minimizing energy consumption for artificial lighting in a typical classroom of a Hellenic public school aiming for near Zero Energy Building using LED DC luminaires and daylight harvesting systems. Energy Build. 2019, 194, 201-217. [CrossRef]

17. Misirlısoya, K.G. Adaptive reuse strategies for heritage buildings: A holistic approach. Sustain. Cities Soc. 2016, 26, 91-98. [CrossRef]

18. Getty Conservation Institute. Sustainability and Heritage in a World of Change, Professionals Forum Held at Getty Centre. 2011. Available online: http://www.getty.edu/conservation/public_programs/sustain.html (accessed on 11 May 2015).

19. Del Hoyo-Meléndez, J.M.; Mecklenburg, M.F.; Doménech-Carbó, M.T. An evaluation of daylight distribution as an initial preventive conservation measure at two Smithsonian Institution Museums, Washington DC, USA. J. Cult. Herit. 2011, 12, 54-64. [CrossRef]

20. Di Salvo, S. Innovation in lighting for enhancing the appreciation and preservation of archaeological heritage. J. Cult. Herit. 2014, 15, 209-212. [CrossRef]

21. Kurnia, K.; Azizah, D.; Mangkuto, R.; Atmodipoero, R. Visual Comfort Assessment Using High Dynamic Range Images under Daylight Condition in the Main Library Building of Institut Teknologi Bandung. Procedia Eng. 2017, 170, 234-239. [CrossRef]

22. Ferretti, V.; Bottero, M.; Mondini, G. Decision making and cultural heritage: An application of the Multi-Attribute Value Theory for the reuse of historical buildings. J. Cult. Herit. 2014, 15, 644-655. [CrossRef]

23. Dutta, M.; Husain, Z. An application of Multicriteria Decision Making to built heritage. The case of Calcutta. J. Cult. Herit. 2009, 10, 237-243. [CrossRef]

24. Yildirim, M.; Yildırım, M. Assessment of the decision-making process for re-use of a historical asset: The example of Diyarbakir Hasan Pasha Khan, Turkey. J. Cult. Herit. 2012, 13, 379-388. [CrossRef]

25. Wang, H.-J.; Zeng, Z.-T. A multi-objective decision-making process for reuse selection of historic buildings. Expert Syst. Appl. 2010, 37, 1241-1249. [CrossRef]

26. Yung, Y. Multi-criteria decision making for urban built heritage conservation: Application of the analytic hierarchy process. J. Build. Apprais. 2009, 4, 191-205.

27. Chen, C.-S.; Chiu, Y.-H.; Tsai, L. Evaluating the adaptive reuse of historic buildings through multicriteria decision-making. Habitat Int. 2018, 81, 12-23. [CrossRef]

28. Peterson, N.L. The Space between Research and Practice: A Critical Evaluation of Computer-Based Lighting Metrics. Master's Thesis, University of Washington, Seattle, WA, USA, 2015.

29. UNI 11630. Light and Lighting-Criteria for the Preparation of the Lighting Design; EU: Brussels, Belgium, 2016.

30. UNI EN-12464-1. Light and Lighting-Lighting of Work Places-Part 1: Indoor Work Places; EU: Brussels, Belgium, 2011.

31. IES. Lighting Handbook: The Standard Lighting Guide; Illuminating Engineering Society of North America (Classic Reprint): New York, NY, USA, 2018.

32. Italian Material Standard 15193-1. Energy Performance of Buildings-Energy Requirements for Lighting-Part 1: Specifications, Module M9; EU: Brussels, Belgium, 2017.

33. CEN/TS 16163. Conservation of Cultural Heritage-Guidelines and Procedures for Choosing Appropriate Lighting for Indoor Exhibitions; EU: Brussels, Belgium, 2014.

34. CEN TC 346-UNI EN 16883. Conservation of Cultural Heritage-Guidelines for Improving the Energy Performance of Historic Buildings; EU: Brussels, Belgium, 2017.

35. ANSI/IES TM-30-18. IES Method for Evaluating Light Source Color Rendition; ANSI/IES: Washington, DC, USA, 2018.

36. Duffie, J.A.; Beckman, W.A. Solar Engineering of Thermal Processes, 4th ed.; John Wiley \& Sons Inc.: Hoboken, NJ, USA, 2012.

37. Hendrick, C.; Martyniuk, O.; Spencer, T.J.; Flynn, J.E. Procedures for Investigating the Effect of Light on Impression: Simulation of a Real Space by Slides. Environ. Behav. 1977, 9, 491-510. [CrossRef]

38. Bell, E. An Exploratory Lighting Study on the Effects of Correlated Color Temperature in Senior Living. Master's Thesis, Ohio State University, Columbus, OH, USA, 2018. 
39. Ministry of Cultural Heritage and Activities in Italian Language. D.M. 10/05/2001 Guidance Document on Technical-Scientific Criteria and Museum Operating and Development Standards; D. Lgs. n.112/98 Art. 150 Comma 6; MiBAC: Roma, Italy, 2001.

40. Li, D.H.; Lam, T.N.; Wong, S. Lighting and energy performance for an office using high frequency dimming controls. Energy Convers. Manag. 2006, 47, 1133-1145. [CrossRef]

41. Li, D.H.; Cheung, K.; Wong, S.; Lam, T.N. An analysis of energy-efficient light fittings and lighting controls. Appl. Energy 2010, 87, 558-567. [CrossRef]

42. Bellia, L.; Fragliasso, F. Automated daylight-linked control systems performance with illuminance sensors for side-lit offices in the Mediterranean area. Autom. Constr. 2019, 100, 145-162. [CrossRef]

43. Bellia, L.; Fragliasso, F.; Riccio, G. Daylight fluctuations effect on the functioning of different daylight-linked control systems. Build. Environ. 2018, 135, 162-193. [CrossRef]

44. CIE 136. Division 4. Guide to Supplement the Lighting Recommendations and Standards for Roads and Areas of Public Use; CIE: Cambridge, UK, 2000.

45. UNI EN. ISO 6385: 2004_Principles of Ergonomics in the Design of Work Systems; ISO: Geneva, Switzerland, 2004.

(C) 2019 by the authors. Licensee MDPI, Basel, Switzerland. This article is an open access article distributed under the terms and conditions of the Creative Commons Attribution (CC BY) license (http://creativecommons.org/licenses/by/4.0/). 